\title{
Transgressão e utopia: Fausto na estética de Ernst Bloch
}

\author{
Transgression and utopia: Faust in Ernst Bloch's aesthetics
}

\author{
Ubiratane de Morais Rodrigues \\ ubiratanerodrigues@gmail.com \\ (Universidade Federal do Maranhão, Maranhão, Brasil)
}

\begin{abstract}
Resumo: 0 objetivo deste artigo é apresentar a transgressão como uma categoria dialética fundamental da filosofia de Ernst Bloch. Para isso, partimos da interpretação original de Bloch sobre o Fausto de Goethe. A relação estabelecida entre Filosofia e Literatura nas análises do Fausto revela que a conceituação de Fausto como figura-modelo da transgressão é a pedra angular, na literatura, capaz de movimentar uma reflexão estética sobre as potencialidades utópicas da arte.
\end{abstract}

Palavras-chave: Transgressão; Fausto; Utopia Concreta.
Abstract: The purpose of this article is to present transgression as a fundamental dialectical category in Ernst Bloch's philosophy. For this, we start from Bloch's original interpretation of Goethe's Faust. The relationship established between Philosophy and Literature in Faust's analyzes reveals that the conceptualization of Fausto as a model figure of transgression is the cornerstone, in literature, capable of moving an aesthetic reflection about the utopian potentialities of art.

Keywords: Transgression; Faust; Concrete Utopia.

DOI: http://dx.doi.org/10.11606/issn.2318-9800.v26i3p75-92

\section{Introdução}

Hans-Georg Gadamer (1998, p. 92), em “Filosofia e Literatura” de 1981, afirma que, pela relação privilegiada com a interpretação, a obra literária ganha a vizinhança da filosofia. Vizinhança sem muros, vizinhança de diálogos, de contaminação, de desconfiança e distanciamento. A separação entre literatura e filosofia é tênue, mas questões ontológicas e hermenêuticas preservam o território singular de cada uma das áreas. Nesse sentido, caminhar neste espaço entre filosofia e literatura é cuidar para não fazer uma serva da outra. É nessa relação entre as duas áreas que caminhou Ernst Bloch ao se deparar com a literatura. Dela soube ser um bom vizinho, pois,

\footnotetext{
* Este artigo faz parte de minha tese de doutorado apresentada ao Programa de Pós-Graduação em Filosofia do Departamento de Filosofia da Faculdade de Filosofia, Letras e Ciências Humanas da Universidade de São Paulo no ano de 2020 sob a orientação do Prof. Dr. Oliver Tolle. A mesma teve financiamento de bolsa de estudo nível doutorado da Fundação de Amparo à Pesquisa e ao Desenvolvimento Científico e Tecnológico do Maranhão - FAPEMA.
} 
como nos disse Gadamer, "o encontro com uma grande obra de arte é sempre, eu diria, como um diálogo frutífero, um perguntar e responder ou um ser indagado e precisar responder - um verdadeiro diálogo junto ao qual algo veio à tona e 'permanece'” (idem, p. 101). O Fausto de Goethe permitiu um encontro permanente com a filosofia de Bloch, sendo Fausto o modelo que permaneceu inquietando-o e fazendo-o responder, numa tênue simbiose que levou Fredric Jameson a afirmar que o trabalho de Bloch "no seu todo pode, de certo modo, ser visto como um imenso comentário ao poema de Goethe" (Jameson, 1985, p. 111). Essa afirmação faz sentido quando se acompanha a obra de Bloch e se percebe a presença constante de Fausto. Entretanto, Bloch não foi o único privilegiado com esse encontro; teve que fazer vizinhança também com outros gigantes, que inclusive chegaram primeiro, como por exemplo, Hegel e Schelling, e, entre outros, T. W. Adorno, W. Benjamin, Benedetto Croce, M. Berman, para não citar a recepção literária e sociológica. Uma comunidade hermenêutica que produziu uma fortuna crítica quase inesgotável. Entre os colaboradores dessa fortuna crítica no Brasil, é digno de nota o trabalho de Marcus Mazzari na apresentação, comentários, notas e revisão da tradução do Fausto: uma tragédia em dois volumes, bilíngue, feita do original alemão por Jenny Klabin Segall ${ }^{1}$. Pode-se nessa edição ter um panorama geral e rigoroso do processo de escrita da obra por Goethe, assim como suas influências e as sutilezas hermenêuticas da poética do Fausto. Nesse sentido, não há necessidade de reconstruir aqui essa obra em forma historiográfica, mas situar no debate filosófico a hermenêutica blochiana acerca do conceito de transgressão, em outras palavras, localizar no argumento blochiano a potência fáustica da transgressão.

Quando Goethe optou por não publicar a segunda parte do Fausto, pela evidente incompreensão de seu texto na recepção de seu tempo, ele não tinha dimensão que a posteridade de sua tragédia fosse sua própria atualidade, pois, ainda que mergulhados no legado dos mais diversos intérpretes, essa obra não para de fazer vizinhos e suscitar novas questões hoje, ${ }^{2}$ sendo a interpretação blochiana do Fausto de Goethe uma prova exemplar da contínua renovação interpretativa dessa obra.

Para Bloch, a transgressão de Fausto está ligada diretamente ao conteúdo de sua aposta, a busca do instante plenificado, como veremos mais à frente. Algo the falta, nada o satisfaz, o mundo empobrecido a seus olhos necessita do novo. Em busca desse novo, ele inicia uma viagem dialética, onde cada estação de chegada já é estação de partida, pois não the preenche o espírito a experiência alcançada, faltathe o instante lindo. A decisão de partir para uma nova estação é sempre mediada pela experiência alcançada na jornada anterior.

1 Quanto ao trabalho minucioso de Mazzari, conferir (Galle, 2004, p. 229-233).

2 A mais recente no Brasil é o livro de Marcus Mazzari lançado em 2019. Cf. Mazzari, 2019. 


\section{Fausto em metamorfoses}

A acurada atenção sobre a obra de Goethe não é desvinculada do contexto histórico e da metamorfose por que passaram as histórias do tema Fausto na literatura. Em Goethe, não há mais um pacto com Mefistófeles no sentido antigo, mas há uma aposta, e, com esta, ele retira aquilo que havia em outras histórias do Fausto: o medo do inferno, riquezas, mulheres etc. A aposta é, na obra de Goethe, uma roupagem para nomear aquilo cuja falta apenas se pressente. Segundo Bloch, entre o Proto-Fausto de 1587 e o Fausto de Goethe ocorreu “uma mudança ideológica de lugar, que correspondeu ao modelo econômico individualista em surgimento com o típico retardamento alemão” (Bloch, 2006, p. 95). A relação com a ideologia está associada às condições materiais que divergiam tanto na Inglaterra de Marlowe de 1604, quanto na Prússia de Goethe. 0 pacto antigo perdia o sentido diante das novas relações sociais, e passou por sua primeira atualização com Lessing, ${ }^{3}$ que, segundo nosso autor, direcionou o pacto-aposta para a relação inferno-conhecimento. As efemeridades materiais perderam o sentido e o caminho para a redenção fora iniciado na história do Fausto. Lessing atualiza a história atento à relação entre o desenvolvimento do sujeito e as aspirações de sua época. Bloch acrescenta: “é verdade que a alma de Fausto ainda é entregue ao inferno, mas apenas numa visão onírica” (Bloch, 2006, p. 95). Lessing foi responsável assim pela redenção da alma de Fausto no céu e na terra, fazendo-o representar o modelo da subjetividade moderna que busca o infinito malgrado sua finitude.

Sem desconsiderar a época em que o Fausto de Goethe foi escrito, a recepção blochiana não restringe o personagem à forma burguesa da individualidade acumulativa da propriedade privada, mesmo que paradoxalmente tenhamos um Fausto proprietário na segunda parte da tragédia goethiana. 0 objeto de interesse maior de Bloch é a potência utópica do Fausto e o modelo de transgressão mediada que percorre toda a obra. Embora reconhecendo as questões econômicas e sociais, ele não se detém nelas, como Marshall Berman, que anunciou o Fausto, seguindo a linha lukacsiana, como tragédia do desenvolvimento em seu livro Tudo que é sólido desmancha no ar: a aventura da modernidade. No capítulo dedicado ao Fausto de Goethe, ele desenvolve essa tese através daquilo que ele chamou de "as três metamorfoses de Fausto", a saber: o sonhador, o amador e o fomentador. Para Berman (1986, p. 39), a própria ideia de modernidade está diretamente ligada

\footnotetext{
3 É importante salientar que Lessing não publicou uma história do Fausto; temos de seu projeto um fragmento e alguns comentários reunidos em suas obras completas em forma de cartas. Assim como Goethe, a história de Fausto chegou a Lessing pelo teatro de marionetes. Seu projeto foi pensado levando em consideração a Alemanha de sua época e suas estruturas morais. Cf. Lessing, Gotthold Ephraim. (1997). “D. Fausto”. In: Werke (1758-1759). Bd. 4. Frankfurt am Main: Herausgegeben von Gunter E. GRIMM. DKV. Conferir ainda Baptista e Oliveira (2014).
} 
à figura de Fausto como um de seus heróis culturais. A atenção ao Fausto e sua atualidade dada por ele refletem sua aproximação à literatura pelo caminho de um desenvolvimento do que se chama modernidade. Ele reconstitui a dialética interna do Fausto de Goethe como desenvolvimento da modernidade, com a hipótese de que há nessa obra uma espécie de reflexo social apreendido por Goethe. Como Bloch e a recepção da obra no século XX, ele considera que o Fausto de Goethe "ultrapassa todos os outros, em riqueza e profundidade de perspectiva histórica, em imaginação moral, em inteligência política, em sensibilidade e percepção psicológica" (idem, p. 40). Isso também reforça sua tese de que o período em que Goethe escreve é um dos mais revolucionários da história.

A argumentação de Berman parte dessa dialética entre o Fausto (sua produção) e o surgimento da modernidade. O leitmotiv para essa relação é o "desejo de desenvolvimento" que impulsiona Fausto, impulso que segundo o crítico em questão é aquilo que diferencia o Fausto de Goethe dos outros até então existentes. Assim, na linha bermaniana, o desejo de desenvolvimento do Fausto de Goethe estabelece uma "afinidade entre o ideal cultural do autodesenvolvimento e o efetivo movimento social na direção do desenvolvimento econômico" (idem, p. 41). Essa afinidade é uma necessidade do homem moderno, seu autodesenvolvimento depende da transformação do mundo físico, social e moral. É juntamente nessa perspectiva que Berman caracteriza a obra de Goethe como tragédia do desenvolvimento. Nessa interpretação, as três metamorfoses por que passa Fausto são a própria metamorfose do mundo. A primeira é a saída da interioridade, de seu pequeno mundo, tanto de seu quarto e tudo que o circunda quanto do mundo idílico em que vive, onde a expressão de sua interioridade não encontra objeto para manifestação. Esta metamorfose está ligada à abertura do mundo pelos anseios, desejos e sonhos do humano, que agem modificando sua estrutura interior e alargando suas fronteiras espaciais. Em certos limites, pode-se afirmar que que Bloch concordaria com a interpretação bermaniana, na medida em que os sonhos diurnos e o anseio do melhor alargam tanto a subjetividade do indivíduo quanto o meio em que vive.

Desde que saiu de seu quarto para passear, Fausto não parou de agir; nestes termos, o impulso do desenvolvimento gira em torno da ação. Berman faz uma importante observação sobre a ação de Fausto: segundo ele, a ajuda de Mefistófeles é imprescindível na criação de novos horizontes, mas a ação é exclusivamente fáustica. Berman não perde de vista o capitalismo em desenvolvimento e a modernidade em sua velocidade no momento da evolução de Fausto, levando-o a afirmar que a tragédia do desenvolvimento passa pela liberação das potências criativas e destrutivas do homem moderno, tal como na dialética interna do Fausto.

A segunda metamorfose de Fausto defendida por Berman aprofunda a primeira, a saber: realização da destruição do pequeno mundo na figura de Gretchen. A tragédia 
de Gretchen revela o alto preço do desenvolvimento moderno, e a impossibilidade "de diálogo entre um homem aberto e um mundo fechado" (idem, p. 58). A terceira metamorfose é a do fomentador, que melhor atende aos interesses de Berman ao defender que o Fausto é uma aventura da modernidade em forma literária. Esta metamorfose acontece na segunda parte da obra de Goethe, escrita ente 1825 e 1831. Segundo Berman, Fausto

conecta seus rumos pessoais com as forças econômicas, políticas e sociais que dirigem o mundo; aprende a construir e a destruir. Expande o horizonte de seu ser, da vida privada para a pública, da intimidade para o ativismo, da comunhão para a organização. Lança todos os seus poderes contra a natureza e a sociedade; luta para mudar não só a sua vida, mas a vida de todos. Assim encontra meios de agir de maneira efetiva contra o mundo feudal e patriarcal: para construir um ambiente social radicalmente novo, destinado a esvaziar de vez o velho mundo ou a destruí-lo (idem, p. 60-61).

É nessa metamorfose que o impulso do desenvolvimento se ergue com mais força, toda a ação é de Fausto, que tem o controle de todo o processo de sua ação sobre o mundo. Não há espaço para sonhos ou fantasias, ele cria um mundo novo a partir da própria natureza e do trabalho humano. 0 impulso se alinha com o desenvolvimento econômico, o autodesenvolvimento espelhou-se no mundo tanto nas formas econômicas quanto políticas.

Contextualizando a época da escrita do Fausto de Goethe no que diz respeito à política, Benjamin compara Goethe a Napoleão. Segundo ele, o contexto sociopolítico era de uma burguesia emancipada "sob a forma política do despotismo" (Benjamin, 2009, p. 155). Os tormentos dos dois eram os mesmos: o impossível, o incomensurável, o insuficiente, mas enquanto Napoleão fracassou diante disso, Goethe, "ao contrário, pode-se dizer que, quanto mais envelhecia, tanto mais adaptava sua vida a essa ideia política, designando-a conscientemente de incomensurável, insuficiente, elevando-a a uma pequena imagem primeva de sua ideia política” (idem, p. 156), revertendo parte disso na segunda parte do Fausto. Neste ponto, Benjamin e Berman se complementam.

Mesmo não trabalhando da perspectiva da transgressão, Berman corrobora com nosso argumento da transgressão neste artigo quando interpreta que o objetivo de Fausto é "não desperdiçar nada nem ninguém, passar por cima de todas as fronteiras: não só a fronteira entre a terra e o mar, não apenas os limites morais tradicionais na exploração do trabalho, mas também o dualismo humano primário do dia e da noite" (Berman, 1986, p. 64), ainda que essa ultrapassagem de barreiras seja mediada pelo desenvolvimento da economia moderna. Fausto construiu um novo mundo, e nesse processo foi também modificado por sua jornada, tornando-se moderno assim como todo seu entorno foi criado à sua imagem, portanto, modernizado. Contudo, a consequência de toda essa aventura pode ser resumida no seguinte argumento de 
Berman: “é como se o processo de desenvolvimento, ainda quando transforma a terra vazia num deslumbrante espaço físico e social, recriasse a terra vazia no coração do próprio fomentador. É assim que funciona a tragédia do desenvolvimento" (idem, p. 67).

Ainda que Berman esteja ligado à corrente lukácsiana e sua interpretação enfatize o desenvolvimento capitalista, a realidade de Goethe e a expansão da indústria na Inglaterra do século 18, ele afirma que a empreitada do herói trágico não é capitalista em seus objetivos últimos, tampouco em suas motivações. Existe, segundo sua interpretação, uma diferença entre Mefistófeles e Fausto: o primeiro tem uma visão que poderia ser associada ao capitalista, enquanto os empreendimentos de Fausto não são em proveito próprio, mas têm em vista o futuro da humanidade. Essa interpretação decorre de uma aproximação de Goethe com os socialistas utópicos franceses, pois, na velhice, Goethe aspirava viver para ver realizados os projetos que lia no jornal socialista Le Globe, justamente quando estava escrevendo as últimas páginas do Fausto. Goethe estava admirado com os projetos de SaintSimon e dos saint-simonianos. Projetos esses que, segundo Berman, realizam-se na última parte do Fausto. Contudo, fica o alerta de Benjamin, segundo o qual, "não se pode enfatizar de modo suficientemente vigoroso quanta apologia política, quanta experiência da antiga atividade palaciana de Goethe está presente nessa parte posterior, especialmente nas cenas que transcorrem na corte imperial e nos acampamentos militares!” (Benjamin, 2009, p. 173). Embora Benjamin reconheça no Fausto elementos de íntima política.

\section{Fausto e a transgressão}

Não é possível afirmar a partir dos argumentos de Berman que há no Fausto de Goethe uma utopia. Ao contrário, os argumentos de Bloch em sua hermenêutica do Fausto têm o utópico como ponto central de análise. Mesmo ele não desenvolvendo a relação direta entre o capitalismo e o autodesenvolvimento de Fausto, ele não separa suas análises do Fausto de Goethe do mundo onde ocorre o processo dialético de constituição da subjetividade transgressora de limites na figura-modelo Fausto. 0 fio condutor de Bloch é a aposta no instante plenificado (Bloch, 2006, p. 96).

A relação entre o teor da aposta e o instante plenificado está diretamente ligada ao autoencontro do sujeito consigo mesmo, à identidade almejada, à reconciliação sujeito-objeto e ao que Bloch denomina de pátria. Lembre-se que aposta não é mais o mesmo que pacto: a diferença se estabelece aqui por uma nuance metafísica, mesmo que esta não se refira mais ao transcendente além-mundo. 0 objeto de desejo de Fausto não está no espaço - não é um lugar ou uma coisa, mais um instante - encontra-se no tempo, não se concretiza em bens materiais nem em prazeres do 
corpo. Embora esteja no tempo, o desejo desse instante ao qual Fausto se direciona é uma ideia concreta, "tão concreta que nem se trata mais de uma ideia, e sim de um experimento, ainda que seja um bem direcionado, um experimento direcionado para aquilo que plenifica" (idem, p. 96). Essa busca que inquieta todo ser humano é ativada em Fausto, que não se prende à sua vida burguesa, não se satisfaz com o conhecimento, as mulheres, a luxúria, a vida promíscua ou o dinheiro; ele quer experimentar o mundo, ávido por recolher em si algo capaz de impulsioná-lo com mais força e mais à frente transgredindo todas as barreiras de seu autodesenvolvimento. Nesse sentido, a relação com o mundo não é puramente subjetivista, é uma relação sujeito-objeto em busca de sua identidade.

A aposta é feita no Quarto de trabalho, no segundo encontro que Fausto tem com Mefistófeles. ${ }^{4}$ Este se oferece para ser lacaio e criado de Fausto, que the pergunta: "e com que ofício retribuo os teus?" (Goethe, 2004, p. 65), e a resposta de Mefistófeles é de que Fausto tem tempo para pagar. Entretanto, Fausto conhece as astúcias de Mefisto e sabe que há um preço pelos serviços. Percebe-se aqui uma resistência de Fausto à relação crédito-débito entre ele e Mefistófeles. Coagido a dizer a condição do preço pelos serviços, Mefistófeles diz que servirá Fausto em tudo neste mundo, e que depois da morte Fausto o servirá. Uma chave de leitura importante nesse processo do crédito-débito é que Goethe não coloca mais a condição clássica de Mefistófeles servir por 24 anos na terra seu senhor, como aconteceu no Doutor Fausto de Marlowe, quando, na cena 3, Mefistófeles pergunta “Agora, Fausto, o que queres de mim?”, o Doutor Fausto responde (Marlowe, 2018, p. 67):

Que me acompanhes enquanto eu viver

Fazendo tudo o que Fausto mandar:

Derrubar a lua de sua esfera

Ou afogar o mundo no oceano.

E enviando Mefistófeles para anunciar seu desejo do pacto com Lúcifer, Fausto determina o tempo que pretende ser servido e o que deseja na relação créditodébito (idem, p. 73-75):

Em troca de mais vinte e quatro anos

De uma existência de volúpia plena,

\footnotetext{
4 Para Walter Benjamin, Mefistófeles na obra de Goethe, já é "muito menos o demônio da doutrina cristã do que o espírito telúrico das tradições mágicas e cabalísticas", enquanto Fausto seria a figura de "homem primitivo titânico, o irmão gêmeo de um Moisés planejado em épocas passadas e que também devia tentar arrancar do Deus-natureza o segredo da criação". Estas características dos dois personagens principais da obra já estavam presentes no Urfaust de 1775 , segundo Benjamin. Cf. Benjamin, 2009, p. 171.
} 
Tendo a ti sempre para me servir

Para dar tudo aquilo que eu deseje,

Dizer-me tudo aquilo que eu pergunte,

Matar quem odeio, alçar a quem amo

E sempre obedecer minha vontade

Vai, e retorna ao poderoso Lúcifer

Encontra-me de novo à meia-noite

E explica-me o que planeja teu Mestre.

No Fausto de Goethe não há um tempo determinado para os serviços de Mefistófeles a Fausto, o tempo nessa obra escorre como fluxo contínuo, mas finito para Fausto enquanto homem, e eterno para Mefisto. Embora Fausto não se interesse pelo outro mundo, visto que seu ceticismo metafísico já ficou há muito tempo para trás na cena da Noite, ele viverá muitos prazeres em sua jornada, mas, por isso mesmo, ele diz com certeza e arrogância (Goethe, 2004, p. 167).

Nem me interessa ouvir, deveras,

Se há, no Além, ódio, amor, estima,

E se há também em tais esferas

Algum “embaixo" e algum “em cima”.

A sedução de Mefistófeles com seus créditos chega ao ponto de oferecer a Fausto o que nunca outro ser humano teve (não anuncia o que seria isso). Mas Fausto acredita ainda nas profundezas subterrâneas dos anseios humanos e sabe que em seu afã supremo o ser humano nunca será desvendado, nunca terá satisfação plena com os bens materiais ou prazeres efêmeros. Benjamin chega a apontar que "o ponto crucial da obra é o seguinte: a ambição selvagem e inquieta de Fausto pelo absoluto frustra a arte de sedução de Mefisto e o círculo dos prazeres sensuais é logo percorrido sem aprisionar Fausto" (Benjamin, 2009, p. 172). Mefisto insiste com sua sedução, diz que fará com que Fausto se curve aos prazeres. Fausto inquieto, e diante dessa provocação de Mefistófeles, introduz então a aposta com Mefisto para regular a relação crédito-débito (Goethe, 2004, p. 169).

Se eu me estirar jamais num leito de lazer,

Acabe-se comigo, já! 
Se me lograres com deleite

E adulação falsa e sonora,

Para que o próprio Eu preze e aceite,

Seja-me aquela a última hora! Aposto! E tu?

Mefistófeles aposta e Fausto então arremata os termos dessa (idem, ibidem):

E sem dó nem mora!

Se vier um dia em que ao momento (Augenblike)

Disser: Oh, para! és tão formoso! (Verweile doch! du bist so schön!)

Então algema-me a contento,

Então pereço venturoso!

Repique o sino derradeiro,

A teu serviço ponhas fim,

Pare a hora então, caia o ponteiro,

O Tempo acabe para mim!

Interessante notar que o próprio Mefistófeles parece não entender a aposta, a ponto de pedir a Fausto um contrato por escrito e assinado com sangue, típico dos pactos anteriores, como no caso do Doutor Fausto de Marlowe, em que, na cena 5, o Doutor Fausto sela o pacto com Mefistófeles, que exige daquele um contrato escrito com sangue como garantia. O Doutor Fausto confirma que escreverá. 0 pacto é selado com sangue, mesmo com dificuldade e ajudado por Mefistófeles, pois o sangue do Doutor Fausto coagula na hora da escrita. Entretanto, este tipo de pacto não tem mais lugar na obra de Goethe: Fausto se resume a dizer que: "Não há perigo de eu romper o pacto! O afã do meu vigor completo" (idem, p. 173). E Fausto, diante da aposta, inicia seu caminhar pelo pequeno mundo, com a certeza de que não pensa em alegrias; mas isso não o impedirá de vivenciar prazeres e poder. Ele quer tudo, viver a humanidade em si. Quer tudo sem freios. O tempo, porém, ele quer parar por um instante. Fausto reafirma seu desejo do todo (idem, p. 175),

Não penso em alegrias, já to disse.

Entrego-me ao delírio, ao mais cruciante gozo,

Ao fértil dissabor como ao ódio amoroso. 
Meu peito, da ânsia do saber curado,

A dor nenhuma fugirá do mundo,

E o que a toda a humanidade é doado,

Quero gozar no próprio Eu, a fundo,

Com a alma the colher o vil e o mais perfeito,

Juntar-lhe a dor e o bem-estar no peito,

E, destarte, ao seu Ser ampliar meu próprio Ser,

E, com ela, afinal, também eu perecer.

Mesmo diante do alerta da impossibilidade desse feito, dado por Mefistófeles, pertencer somente a Deus, Fausto o quer, ele deseja o todo em si, quer ser o próprio Deus, e em certa medida será, construirá um novo mundo, destruirá velhas formas de vida, decidirá sobre a guerra, sobre a morte e a vida das pessoas. Mas, no fim, Fausto revelará em si as palavras de Mefistófeles logo após a aposta, "no fim sereis sempre o que sois” (idem, p. 177). Quem é Fausto? Para Bloch, a representação do humano que está sempre transgredindo seus limites, e, na literatura, representa a figura-modelo da transgressão por excelência.

Sob o signo da incondicionalidade, do sentimento de sair de si sempre em busca de algo que the falta, desse desejo de um minuto de deleite onde ele possa dizer “demora eternamente! És tão lindo!", sustenta-se a transgressão no Fausto de Goethe. O utópico surge em uma figura que é transformada completamente em seu percurso que vai do Quarto de trabalho até o momento em que sucumbe diante de Mefistófeles na segunda parte da obra. Saciado pelo conhecimento, já que se julgava sábio, Fausto quer algo a mais. Ele quer o instante plenificado, na interpretação de Bloch: "Sublime como no primeiro dia permanece a vontade de uma intenção que não pode ser limitada à sua forma burguesa: a mediação do sujeito no mundo e por intermédio do mundo, tendo como base o problema do instante plenificado" (Bloch, 2006, p. 96). Bloch salienta que essa figura que busca esse instante é um ser humano, um humano que não é uma abstração, mas concreto que transcende seus limites de forma imanente, já que não é o além-mundo que interessa a Fausto. A saída de si rumo ao instante plenificado perpassa toda uma condição de experimentação concreta do mundo.

Vestido com o capote mágico que o carrega pelos ares, Fausto vive tudo o que the sucedeu e o transcende a partir da mais densa e ampla vontade de atingir o instante, a mesma que determina a aposta. 0 centro faustiano atravessa tanto o mundo quanto o céu, sendo que ambos, numa mediação gradativa, atuam como símbolos em torno dele; todavia, no final das contas nem o mundo nem seu céu são capazes de abranger este centro excêntrico (idem, p. 97). 
A viagem dialética de Fausto o faz transgredir todos os momentos concretos, indo mais além. Ele busca a dilatação de si-mesmo na experiência com o real, não conhece os limites; ou melhor, se conhece, busca dilatá-los criando outros limites para poder rompê-los novamente. Só a transgressão dos limites impostos pode enriquecer o homem, mas a transgressão só acontece se o humano for capaz de compreender, assimilar e ressignificar seu próprio momento existencial: de si com o mundo, não isoladamente. Assim, "cada desfrute alcançado é riscado por um novo desejo bem próprio despertado por ele. Além disso, cada ponto de chegada atingido é refutado por um movimento novo que o contradiz, pois algo está faltando, o instante lindo ainda está ausente" (idem, p. 97). O sujeito Fausto vai mudando à medida que passam suas experiências no mundo e sente a vulgaridade do prazer efêmero. Fausto passa por uma formação, no sentido de experimento e autoconhecimento, superação e transgressão dos instantes vulgares da existência. A mudança de Fausto está para além do mundo reificado burguês em que existe. Transgredir é em certo sentido recomeçar, não do marco zero, pois o espírito já é outro. Isso acontece o tempo todo com Fausto, a força impulsionadora para a frente, como busca constante de algo que falta, assemelha-se ao impulso provado pelos sonhos diurnos; nesse sentido, essa figura transgressora chamada Fausto representa aquele humano que não se contenta com o ruim que está aí, mas caminha mais à frente em busca do novo. Benjamin corrobora com a tese da transgressão quando nos diz que "a busca de Fausto impele-o ao ilimitado, de maneira tanto mais decisiva quanto mais longamente subsiste essa busca” (Benjamin, 2009, p. 172).

A inquietação de Fausto é a inadequação entre a existência e a natureza, entre sujeito e objeto, a inquietação daquele pressentimento que fervilha no fundo de cada ser. Os humanos querem ser aquilo que ainda não são, em decorrência da insatisfação consigo mesmos e da condição de inacabamento do humano. Em marcha, eis nossa condição. Sair, Bloch caracteriza as pessoas que não deixam de seguir seus anseios por algo que lhes falta como indomáveis. A literatura e as artes estão plenas desses exemplos, mas, como bem salienta Bloch, dificilmente passa do livro para o leitor. Seguir os textos analisados por Bloch na literatura seria cair no abismo "quase" sem fim de sua erudição, mas há que se ressaltar que, na vizinhança de sua filosofia ele diferenciou, na literatura, os espíritos que marcham em busca de si e os que marcham em busca de aventura e não se encontram porque ainda estão na lógica do individualismo burguês e os que saem ou buscam a superação dessa ordem tornandose incondicionais. E entre estes últimos, Fausto é a maior figura da inquietação, que sai para buscar a superação de si e de seu Quarto de trabalho, que significa ainda o mundo burguês na forma e na limitada experiência do conhecimento humano no conteúdo, inquietação pelo “Demora eternamente! És tão lindo!”, tornando-se o exemplo de humano utópico. 


\section{A obscuridade do instante vivido}

A compreensão do “Demora eternamente! És tão lindo!” dito por Fausto ao instante tem na obscuridade do instante vivido sua fundamentação filosófica pensada por Bloch. Este conceito sustenta a dialética interna do pensamento blochiano desde a questão “quem é que, dentro de nós, nos impulsiona?" feita no início de 0 princípio esperança até os desdobramentos finais de suas análises sobre as figuras da transgressão e a música no final dessa obra. Entretanto, deve-se levar em conta que este conceito já aparece na segunda edição de Espírito da utopia em 1923, demarcando o caminho da consciência antecipadora desenvolvida só posteriormente na maturidade de seu pensamento.

Na busca da resposta à pergunta "quem nos impulsiona?” Bloch parte do primeiro impulso do humano que é feito por si mesmo a partir de um estado caracterizado por ele de urgência. Aquilo que nos impulsiona para a vida se apresenta primeiro em forma de almejar; se o sentimos, então, passamos a ansiar e esse ansiar pode ter dois destinos: ficar reduzido ao genérico de si mesmo ou direcionar-se para algo. Esse direcionar-se "torna-se um buscar", tem agora um alvo - eis o que é conceituado como pulsão. Bloch estabelece pulsão e necessidade como sinônimos; contudo, reconhece que pulsão é o melhor conceito para seu desenvolvimento filosófico.

Nosso autor então diferencia avidez de pulsão, pois esta última "busca preencher, mediante algo exterior, um vazio, algo de que carece o almejar e o ansiar, algo que falta" (Bloch, 2005, p. 50). Depois de saciada, ela pode por um tempo diminuir, já a avidez é insaciável, o que leva à constatação de que a pulsão se sacia em seu alvo diferente da avidez. Aqui a diferença entre o humano e o animal é estabelecida: o animal dirige-se para o alvo pelo apetite, o humano o faz por antecipação.

Essa digressão demonstra que somos impulsionados por algo que nem mesmo sentimos em nosso interior como urgência na forma fisiológica e que o próprio instante para Bloch é um segredo íntimo, vivência imediata que não é compreendida por nós. Mas já nos percebemos em ação, em movimento para saciar aquilo que falta. Assim, o instante que Fausto ${ }^{5}$ busca é aquele mais imediato, que possa se dar no aqui e agora, onde estamos mais próximos e “cegos”. Não sentimos a própria vida - esse problema ou paradoxo nos coloca frente ao agora.

o mais obscuro é o próprio agora em que nós, como vivenciadores, em cada momento nos encontramos. O agora é o lugar em que o foco imediato da vivência [Erleben] como tal está, onde ele está em questão: assim, o que se acabou de viver é o que se encontra mais imediato, portanto, o que ainda é menos vivenciável (idem, p. 283).

5 Bloch já associava Fausto às suas intuições filosóficas da obscuridade do instante vivido na segunda edição de Espírito da utopia, de 1923. Cf. Bloch, 1964, p. 179. 
O agora se situa na obscuridade do instante, não vivenciamos a experiência em seu acontecimento, mas somente quando ela passou. Isso leva Bloch a pensar o agora não só no tempo, mas também no espaço na chave "agora-aqui". Só do que passou podemos ter experiência consciente, assim como aquilo que virá em forma de angústia ou expectativa. ${ }^{6}$ Mas o acontecimento, o agora, o evento em si, não o vivenciamos. Nesses termos, o que nos impulsiona e o agora não são percebidos. $\mathrm{Na}$ busca da compreensão desse instante, Bloch retoma o ponto de partida da fome, pois aquele que que nos impulsiona no agora busca algo à frente. A interioridade quer algo que existe no exterior, esse impulso para a frente, em busca daquilo que falta; é algo em aberto, o polo oposto do instante obscuro.

Que coisa é esse aberto? Aquilo que ainda pode vir a ser, aquilo que está fermentando no horizonte, porém que já tem as condições concretas em fragmentos para existir no presente. Esse em aberto não é abstrato, mas sustenta-se, como demonstrado acima, na categoria de possível real, no conceito de matéria como sendo-conforme-a-possibilidade. Enquanto na subjetividade existe como sonhos acordados, como imaginação objetiva, pois, como afirma nosso autor: "nas coisas há uma atividade, em que nossos interesses ainda podem ser tratados, uma linha de frente, em que nosso futuro, justamente este pode ser decidido" (Bloch, 2005, p. 284). A busca no fluxo das coisas, ou ainda, no fluxo do mundo, é pelo ainda-não, por aquela realidade que não veio a ser, mas possível, dada as condições concretas para seu surgimento. Segundo Bloch, a busca aqui é pelo futuro autêntico, pelo novum, algo que nunca existiu. Esse algo que se encontra na outra margem é o objeto da consciência antecipatória, ainda está amadurecendo, não como final, visto que a utopia como realização final seria a própria aniquilação da utopia. A busca pelo instante plenificado não finalizou a jornada de Fausto; mesmo na cena final, o céu não é estático. Isso não implica dizer que a consciência antecipatória não busque o ultimum, o final utópico na figura do bem supremo. Ora, a cena do quinto ato do Fausto, região aberta, para além das polêmicas se Fausto perde ou não a aposta, é marcada pela intuição do instante plenificado, pelo ultimum, esse final utópico que a consciência antecipadora almeja (Goethe, 2007, p. 981-983, grifos nossos).

Fausto:

Do pé da serra forma um brejo o marco,

Toda a área conquistada infecta;

Drenar o apodrecido charco,

Seria isso a obra máxima, completa.

\footnotetext{
6 A tese de Janvier Contreras é de que a obscuridade do instante vivido é ponto de partida do pensamento de Bloch. Desta tese, ele desenvolve uma reflexão importante para a compreensão da estética de nosso autor. Cf. Contreras, 2004.
} 
Espaço abro a milhões - lá a massa humana viva, Se não segura, ao menos livre e ativa.

Fértil o campo verde; homens rebanhos,

Povoando, prósperos, os sítios ganhos,

Sob a colina que os sombreia e ampara,

Que a multidão ativa-intrépida amontoara.

Paradisíaco agro, ao centro e ao pé:

Lá fora brame, então, até à beira a maré.

E, se para invadi-la à força, lambe a terra,

Comum esforço acode e a brecha aberta cerra.

Sim! da razão isto é a suprema luz,

A esse sentido, enfim, me entrego ardente:

À liberdade e à vida só faz jus,

Quem tem de conquistá-la diariamente.

E assim, passam em luta e em destemor,

Criança, adulto e ancião, seus anos de labor.

Quisera eu ver tal povoamento novo,

E em solo livre ver-me em meio a um livre povo.

Sim, ao Momento então diria:

Oh! para enfim - és tão formoso!

Jamais perecerá, de minha térrea via,

Este vestígio portentoso! -

Na ima presciência desse altíssimo contento,

Vivo ora o máximo, único momento (Augenblick).

Instante escutado, não contemplado pela visão da sensação, mas pela visão do em-absoluto, antecipação concreta da liberdade que veio ao nosso encontro em forma de arte em seu conteúdo utópico final, liberdade para nós, o obscuro instante vivido tomado pela intuição suprema do artista na forma de poesia. Esse instante plenificado do Fausto é a metafísica concreta que sustenta toda a intuição filosófica do pensamento blochiano a respeito da utopia. Não há paisagem mais desejada que uma terra de homens livres, paisagem do sonho acordado onde o pintor se encontra 
paradoxalmente na obra. Se Fausto estava cego quando disse ao tempo para parar, não parece coincidência que não havia ainda a paisagem utópica para ser contemplada, mas as condições para que esse instante fosse professado como o Máximo. Instante que não é estático, pois havia trabalho, não é um estado fixo, mas uma origem sem princípio como a própria obscuridade do instante vivido. Por isso Bloch pode demonstrar que surge daí a pergunta inconstruível,

Essas experiências de um estado final utópico certamente não tornam esse estado fixo, senão não se trataria de experiências de mera intenção simbólica nem de experiências utópicas, ou até centralmente utópicas. Elas, porém atingem de fato o cerne da latência, mais precisamente como pergunta última que repercute dentro de si mesma (Bloch, 2005, p. 285).

A pergunta não tem resposta pronta, por isso Fausto não nomeou este lugar, não havia ainda lugar pronto. A pergunta por quem somos, por exemplo, não pode ser simplesmente respondida pelos critérios empíricos ou históricos existentes, pois $S$ ainda-não é P. Não nos encontramos onde desejamos. Fausto, mesmo diante de todas as conquistas, ainda almejava um plus, ainda não se bastava, ainda queria a liberdade do nós, estar entre homens livres, e não ser senhor. Assim, o conteúdo da resposta da pergunta informulável está em processo, fermentando. Sendo assim, a profunda admiração é o escopo da pergunta, em que a identificação entre sujeito e objeto ocorre sem possível resposta, sem ponto fixo:

Assim, a pergunta que não pode ser formulada, a pergunta absoluta de fato corre novamente rumo ao instante, para dentro de sua obscuridade. Não como clareira, e sim como indicação inconfundível da escuridão imediata do agora, na medida em que a latência central do seu conteúdo ao menos se retrata nesse perguntar admirativo, nesse admirar-se interrogativo. Se o conteúdo do que se move no agora do que foi tocado no aqui, se externasse positivamente, se fosse um "Demora eternamente! És tão lindo!”, então a esperança imaginada, o mundo esperando teria chegado ao seu alvo (idem, p. 286).

Segundo Bloch, a questão do obscuro tem na própria vida seu fundamento. Aquilo que nos estimula dorme silenciosamente, ferve dentro de nós; por isso nossos sentidos não podem perceber o vivenciado. Não é por acaso que Fausto está cego, e o próprio Édipo no meio do mal não percebeu seu destino e o cumpriu. Mas não se quer viver para sempre nessa obscuridade, não se deseja apenas viver, faz-se necessário vivenciar a experiência. Essa busca de nós mesmos nesse agora-aqui faz do pensamento de Bloch um pensamento da existência em sua mais profunda radicalidade, uma existência que busca sua identificação consigo mesma e com o uno: S não quer ser apenas $\mathrm{P}, \mathrm{S}$ quer também estar em casa. 


\section{Considerações finais}

Fausto como figura-modelo da transgressão funciona, segundo nossos argumentos, para a estética de Bloch, como um arquétipo que fundamenta uma concepção de arte utópica não abstrata. Uma arte capaz de nortear horizontes à espera de serem superados. Isso não implica o fim da autonomia da obra de arte, mas justamente o seu contrário. A transgressão que interessa a Bloch é aquela em que prevalece a categoria da mediação, mediação com os elementos concretos dispostos no contexto de sua execução, como fez Fausto em seu percurso existencial nas duas partes da tragédia goethiana. Entretanto, para concluirmos este artigo, não poderíamos deixar de mencionar que Fausto tem seu par dialético da transgressão, segundo Bloch, é a figura-modelo da transgressão chamada Dom Quixote de La Mancha. ${ }^{7}$

Bloch reconhece que, “dentre os sonhadores incondicionais, ele [Dom Quixote] foi o mais inflexível; logo, age de modo tão ridicularizado quanto grandioso, e representa simultaneamente uma advertência e uma admoestação" (Bloch, 2006, p. 118). A não-mediação da transgressão, ou sua imediaticidade, não permite em Dom Quixote a concretude da ação almejada. Embora haja utopia e esperança no fidalgo, ambas se tornam abstratas, ou seja, a não-mediação com o mundo concreto, a banalização do real, a visão presa ao passado, não permitem ao herói perceber que a sociedade de seu tempo não reserva espaço para seus ideais. Por isso, Dom Quixote não consegue realizar sua façanha, pois "o instante no sentido de Fausto, como aterrissagem de algo incondicionado e sua intenção no presentemente incondicionado, de modo algum existe, para Dom Quixote, como objeto supostamente real" (idem, p. 124). Mas, ainda assim, ao fazer Dom Quixote representar uma figura-modelo de transgressão de limites, Cervantes antecipa as consequências da não-mediação das potências subjetivas com as potências objetivas, deixando-nos a necessidade de transgressão contínua no mundo real. Nestes termos, Fausto e Dom Quixote representam figuras dialéticas da utopia concreta, um no mediatismo, outro no imediatismo, mas ambos necessários para o correto caminho da concretização objetiva dos sonhos acordados. Pois, "o paradigma do mediatismo é mais elevado do que o do imediatismo; ele, no entanto, só é mais elevado na medida em que impõe a si mesmo a consciência radical do imediatismo, como memória a ser mantida em cada mediação" (idem, p. 136, grifo do autor).

Os argumentos postos neste artigo buscam construir uma estética da transgressão a partir do conceito de mediação e utopia concreta; para isso, Fausto é um dos elementos nessa empreitada. A transgressão bem compreendia é um conceito que pode mediar uma hermenêutica da obra de arte em vista de uma utopia concreta.

7 Para uma reflexão sobre Dom Quixote como modelo da transgressão, cf. Rodrigues, 2019. 
Se Fausto é o modelo por excelência para Bloch, é porque, em marcha pelo mundo, transgredindo os limites subjetivos e materiais, tinha suas aventuras mediadas por suas experiências anteriores. A obra de Goethe não se resume à leitura blochiana, mas os argumentos utilizados por Bloch em sua obra $O$ princípio esperança nos incitam a investigar mais de perto o Fausto de forma filosófica, sem que percamos a perspectiva de uma vizinhança saudável e tensa entre filosofia e literatura.

\section{Referências}

Baptista, D. Oliveira, M. H. (2014). T. e comentário:. [Gotthold Ephraim Lessing:] "Décima sétima carta"; das Cartas sobre a literatura mais recente (Fevereiro de 1759). O Percevejo Online, 5 (2), 55-74. DOI: https://doi.org/10.9789/21767017.2013.v5i2.\%25p.

Benjamin, W. (2009). Ensaios reunidos: escritos sobre Goethe. Tradução de Mônica Krausz Bornebusch, Irene Aron e Sidney Camargo. São Paulo: Duas Cidades; Editora 34.

Berman, M. (1986). Tudo que é sólido desmancha no ar: a aventura da modenidade. São Paulo: Companhia das Letras.

Bloch, E. (1964). Geist der Utopie: zweiten Fassung von 1923. Frankfurt am Main: Suhrkamp Verlag.

Bloch, E. (2005). O princípio esperança. Vol. I. Trad. Nélio Schneider. Rio de Janeiro: EDUERJ: Contraponto.

Bloch, E. (2006). O princípio esperança. Vol. III. Trad. Nélio Schneider. Rio de Janeiro: EDUERJ: Contraponto.

Contreras, J. M. (2004). Las huellas de lo oscuro: Estética y Filosofía en Ernst Bloch. Salamanca: S. Esteban.

JAMESON, Fredric. Marxismo e forma: teorias dialéticas da literatura no século XX. Tradução de lumna Maria Simon e Ismail Xavier Fernando Oliboni. São Paulo: Editora HUCITEC, 1985, p. 111

Gadamer, H-G. (1998). Filosofia e Literatura (1981). In: Hermenêutica da Obra de Arte. Tradução Flávio Paulo Meurer. 2. ed. Petrópolis: Editora Vozes.

Galle, H. (2004) Resenha: Goethe, Johann Wolfgang von: Fausto. Uma tragédia. Segunda parte. Tradução do original alemão de Jenny Klabin Segall. Apresentação, comentários e notas de Marcus Vinícius Mazzari. Ilustrações de Eugène Delacroix. Edição bilíngüe. São Paulo: Editora 34, 2007. Pandaemonium germanicum, 8/2004, 229-233. DOI: https://doi.org/10.11606/1982-8837.pg.2004.68428

Goethe, J. W. von. (2004). Fausto. Uma tragédia. Primeira parte. Tradução do original alemão de Jenny Klabin Segall. Apresentação, comentários e notas de Marcus Vinícius Mazzari. Ilustrações de Eugène Delacroix. Edição bilíngue. São Paulo: Editora 34. 
Goethe, J. W. von. (2007). Fausto. Uma tragédia. Segunda parte. Tradução do original alemão de Jenny Klabin Segall. Apresentação, comentários e notas de Marcus Vinícius Mazzari. Ilustrações de Eugène Delacroix. Edição bilíngue. São Paulo: Editora 34.

Lessing, G. E. (1997). “D. Fausto”. In: Werke (1758-1759), Bd 4. Frankfurt am Main: Herausgegeben von Gunter E. GRIMM. DKV.

Lukács, G. (1972). Goethe et son époque. Trad. Francesa de L. Goldmann et Frank. Paris: Nagel.

Marlowe, C. (2018). A Trágica História do Doutor Fausto e a História do Doutor João Fausto de 1587: O nascimento de uma tradição literária. Tradutor: Luís Bueno, Caetano W. Galindo e Mario Luiz Frungillo. Cotia-SP: Ateliê Editorial; Campinas, SP: Editora da Unicamp.

Mazzari, M. V. (2019). A dupla noite das tílias: História e natureza no Fausto de Goethe. São Paulo: Editora 34.

Rodrigues, U. M. (Org.). (2019). Escritos sobre o Espírito da utopia de Ernst Bloch. Porto Alegre, RS: Editora Fi. 284p. Disponível em: https://www.editorafi. org/628bloch. [acesso: 30.11.2021] 